\title{
Critical reflections on H.G. Stoker's (1899-1993) approach towards the elaboration of a Christian philosophy
}

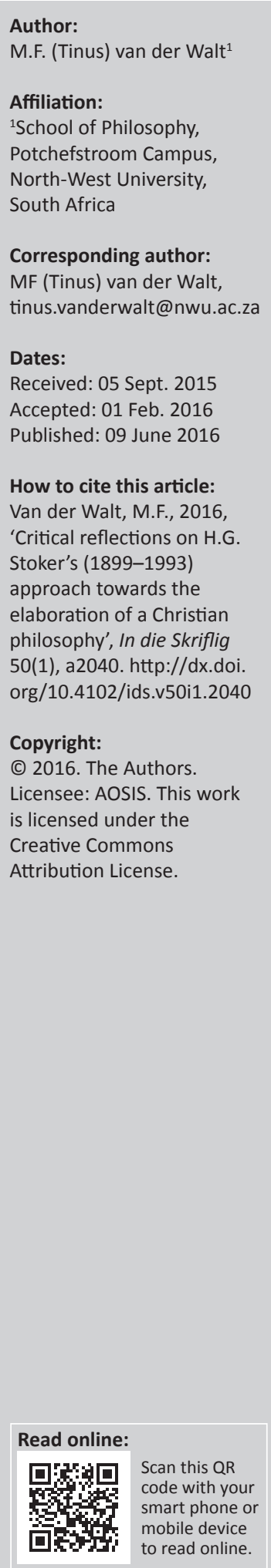

\begin{abstract}
In this article it is argued that the Calvinist philosopher, Hendrik Gerhardus Stoker (1899-1993), adopted a qualified theology-based approach for the elaboration of his Christian philosophy. Being shaped by the nature-super-nature theme, which itself is a method of synthesis, this approach lends itself towards establishing pseudo congruency. In Stoker's case, it is an attempt to reconcile his commitment to an integral Christian philosophy with his antecedent allegiance to reformed theology in its orthodox scholastic expression. Indeed, Stoker has gone further than his reformed predecessors in an effort to develop a Calvinist philosophy. But, instead of piecemeal adjustments, it is proposed that the theology-based approach should be rejected in its entirety if integral Christian scholarship is to flourish.
\end{abstract}

\section{Introduction}

The South African philosopher, Hendrik Gerhardus Stoker, has been widely acknowledged as a formidable thinker inside and beyond the borders of South Africa. At the same time, his ideas seem to have had a mixed and often confusing reception within Calvinist circles. The controversy surrounding certain features of his philosophy reached new peaks with Malan's doctoral thesis (1968) levelling substantial criticisms against them, Stoker (1970:411-433) firmly denying the validity of the said criticism and Hart (1971) coming to Stoker's defence.

These discussions did not settle the main issues satisfactorily. While serious shortcomings in Malan's evaluation were revealed, Hart (1971:120) admitted that there are indeed a number of basic problems in Stoker's philosophy that require further analysis. One such basic problem is signalled by the title with which Stoker originally designated theology, viz. 'queen of the sciences'. This title is associated with a certain cluster of scholastic conceptions that either precludes the possibility of a Christian philosophy or tries to recover such possibility by somehow linking philosophy to theology. Both seem incompatible with the idea of an integral Christian philosophy.

The main question of this article deals precisely with these problems: What approach did Stoker employ in pioneering an integral Christian philosophy and how should it be evaluated? My hypothesis is that Stoker employed a slightly modified theology-based approach and that this approach, to some extent, hindered his pursuit of an integral Christian philosophy. I hope that an analysis of this question will help reformational philosophers as well as other interested scholars to make better sense of the presence of certain problematic conceptions within Stoker's philosophy. I also hope it will serve as a case in point for the importance that maintaining an anti-synthetic attitude has for the vitality of reformational philosophy.

After sketching the historical circumstances and the particular current of Calvinist thought with which Stoker identified, his encyclopaedia of the sciences will be discussed with the purpose of displaying his theology-based approach. Along with the occasional critical remark throughout the discussion, a few reasons will also be provided for why the approach should rather not be emulated by those striving for an integral Christian philosophy.

\section{Historical background}

H.G. Stoker (1899-1993) can rightfully be said to be one of the pioneers endeavouring for the realisation of an integral Christian philosophy. The philosophical tradition that emerged from such efforts is generally known today as reformational philosophy. Characterising Stoker as a pioneer within this tradition is quite suited. To be sure, he was not the sole pioneer, but neither was his work simply an import product from the philosophical pioneering done by Vollenhoven (1892-1978) and Dooyeweerd (1894-1977) (cf. Van der Walt 2007:220) in the Netherlands. 
Stoker was neither a student nor a follower of either Vollenhoven or Dooyeweerd. Vollenhoven was still a pastor in The Hague when Buytendijk referred Stoker to the German phenomenologist Max Scheler for his doctoral studies. This came after the death of Herman Bavinck, the renowned reformed theologian under whom Stoker originally intended to study (Raath 1994:347). Moreover, Stoker was appointed at the Potchefstroom University College in 1925, one year before Vollenhoven and Dooyeweerd accepted their academic chairs at the Free University of Amsterdam. Stoker (1927) also published a series of eight short articles contemplating the principles that should be foundational to a future 'theistic philosophy' only two years after his appointment. ${ }^{1}$ It is thus from the very beginning of his career that he aspired to set forth the outlines of a philosophy that would be Christian. During this period Vollenhoven and Dooyeweerd were busy finding their feet within their own brand of reformational philosophy.

The independent development of a Christian philosophy in South Africa by Stoker does not imply the absence of ties with his Dutch peers in Amsterdam. He rather carved out his own views in relation to those of Dooyeweerd and Vollenhoven, sometimes opposing and at other times concurring with their views. Compare, for example, his monograph 'The new philosophy at the Free University $(\text { Amsterdam })^{\prime 2}$ and the series of eight articles with the main title 'Fragments from the philosophy of the law-idea'. ${ }^{3}$ Moreover, all three pioneers shared deep roots in Dutch Calvinism.

The type of Calvinism which inspired Stoker already from a young age had a peculiar flavour due to its South African context, but it originated from, and retained connections with, Dutch Calvinism. In South Africa, as in the Netherlands, the principles of Calvinism had not really been elaborated in philosophy. The reformers of the earlier generation, particularly Abraham Kuyper and Herman Bavinck, pointed in such a direction. ${ }^{4}$ However, the implementation of Calvinism's principles in the field of philosophy would only commence with the pioneers of reformational philosophy (cf. Van der Walt 2013:6). Before these three thinkers a truly integral Christian philosophy did not exist (Dooyeweerd 1939:198).

\section{Two currents of Calvinist thought}

Given the lack of a Calvinist tradition within philosophical thought to fall back on, the pioneers of reformational philosophy did seek intellectual nourishment from the major 1. Compare also the alternate title of one of his lectures of 1932, viz. 'The philosophy
of the creation idea or the foundational principles of a Calvinist philosophy' (see Stoker 1933a).

2.The title in Afrikaans reads 'Die nuwere wysbegeerte aan die Vrije Universiteit (Amsterdam)' (see Stoker 1933b).

3.The main title of the series in Afrikaans is 'Grepe uit die wysbegeerte van die wetsidee' (see Stoker 1937b; 1937c; 1937d; 1938a; 1938b; 1938c; 1939; 1941a).

4.Van der Stelt (2012) notes that Bavinck's interest broadened after the publication of his famous four volumes 'Gereformeerde Dogmatiek' [Reformed Dogmatics] to various non-theological fields, including philosophy. According to Van der Stelt, various non-theological fields, including philosophy. According to Van der Stelt,
Bavinck 'pressed for constant renewal and a broad understanding of Christian discipleship'. figures in reformed theology. Two more or less distinguishable currents of Calvinist thought sprang forth. In this regard Stoker (1970:218-219) associated himself with the current inaugurated by $\mathrm{H}$. Bavinck and listed the following persons in connection with it: V. Hepp, J. Woltjer, W. Geesinck, P. Prins, H. Steen, C. Jaarsma and F.J.M. Potgieter. ${ }^{5}$ As observed by Stoker, most of these were theologians. Stoker associated the other current of Calvinist thought with Dooyeweerd's philosophy of the law-idea. The names mentioned by Stoker also included D.H.Th. Vollenhoven, S.U. Zuidema, J.P.A. Mekkes, K.J. Popma and H. Van Riessen.

For Stoker, finding intellectual nourishment from his predecessors in the reformed theological tradition meant especially exploring the implications of some of Bavinck's conceptions. These include, among others, an ontology that has, as its main starting point, a distinction between God and the cosmos, the idea that creation itself is revealed to the knower and a certain view regarding the fields of theology and philosophy (Stoker 1970:332; Van der Walt 2013:7). These ideas did not challenge the traditional circumscription of theology's field of study as denoted by its etymology (theos + $\log o s=$ study of god or heilige godgeleerdheid in Afrikaans).

Dooyeweerd, in turn, found inspiration in what he regarded as Kuyper's innovative ideas that pointed towards new avenues. These include, among others, an understanding of God's creational sovereignty that comes to expression in distinct law-spheres, the heart as the religious centre of human existence and the acknowledgement of faith as a boundary function. It is the latter acknowledgement, according to Dooyeweerd (1939:229-230; 1958:12), that led to a proper distinction between theology and philosophy and to a departure from the reformed scholastic view of theology.

There is a significant difference between elaborating the conceptions of one's predecessors (as Stoker did) and deriving inspiration from them (cf. Dooyeweerd's approach). The claim that one current of Calvinist thought expanded the ideas of Bavinck and the other those of Kuyper would, therefore, not be fully correct. In contrast to Stoker, who saw his work as more or less a continuation of Bavinck's contribution to reformed dogmatics, Dooyeweerd (1939) was much more discriminative towards the heritage left by Kuyper. He regarded only some of the creative ideas emerging from Kuyper's work as reflecting the true spirit of Calvinism, while viewing the remaining cluster of concepts, for example those built around the logos theory, as being at odds with it. ${ }^{6}$

Stoker and Dooyeweerd, therefore, had diverging attitudes towards the philosophical ideas of their Calvinist predecessors in theology. Stoker remained much closer to

5.To these could be added the South Africans S.P. van der Walt (1953), J.A. Heyns (1994) and E.J.G. Norval (1950).

6.Vollenhoven, for his part, challenged reformed scholasticism by rejecting, for example, the idea of the immortal substantial soul. According to Tol (2011:203) this also means that 'the Self is no longer the prime pole of thought over against the being of the world'. This challenge, which was met with severe opposition from $V$. Hepp and other reformed theologians, was first initiated by Antheunis Janse, a Hepp and other reformed theologians, was
school principal and friend of Vollenhoven. 
the reformed theologians of the earlier generation and of his own time. Dooyeweerd, together with Vollenhoven, saw some of these very same ideas and theories with which Stoker aligned himself, as serious obstacles to the possibility of developing a philosophy with an integral Christian character. Stellingwerff $(2006: 25,35)$ accordingly describes the beginning of reformational philosophy at the Free University of Amsterdam as a continuous liberation from scholastic remnants in reformed thought. The presence of these remnants should be attributed to the influence of Aristotelian-Thomistic categories, themes and concepts on the successors of John Calvin.

\section{Encyclopaedia and the theology- based approach}

How can Christian scholars ensure that the philosophy they aim to develop will have a genuine Christian character? What is it that makes a philosophy Christian? These are questions about the religious direction of a particular philosophy. Those who opt for some or other version of the theology-based approach tackle this issue by appealing to the science of theology. More specifically, theology is regarded as the key factor for the development of Christian scholarship (Coletto 2009a:292), including that of a Christian philosophy.

As will be argued later, an approach that makes theology the key factor for the development of a Christian philosophy is also found in Stoker. In his philosophy we are confronted by questions regarding the encyclopaedia of the sciences that deserve theoretical reflection in their own right. The fact that Stoker (1961:237-247; 1971:39-44) developed his concern for the relationship between theology, philosophy and the special sciences into a refined and comprehensive encyclopaedia of the sciences is to his credit. For Stoker, however, encyclopaedic issues have an additional relevance due to the envisioned place and role of theology in Christian scholarship. The rationale here is clear: If theology is considered a key factor for Christian scholarship in general, clarifying the relations of the non-theological sciences to theology becomes paramount for the Christian character of those sciences.

\section{Stoker's encyclopaedia of the sciences}

As already mentioned, the distinction and relationships between theology, philosophy and all the other sciences were of great importance for Stoker throughout his career. This is reflected in a series of publications ${ }^{7}$ that span at least the period from the early 1930s up to the early 1970s. In many of these discussions it is apparent that the demarcation between theology and philosophy served as a point of orientation, or as the backdrop upon which the philosophical analysis of the relevant subject was to proceed. As Stoker (2007:chap. 1, par. 2) once expressed it: 'a background or grounding that codetermines and guides the analysis'.
How then did Stoker go about distinguishing between theology, philosophy and the special sciences? How did he define the field and task of these sciences? An answer to these questions must be historically sensitive, especially as Stoker's formulations, being dispersed over multiple publications throughout his career, were rarely identical. Apart from superficial differences in wording, some development did take place in terms of refinement, elaboration and an increase in sophistication. Notwithstanding these differences and changes, a basic underlying scheme remained constant.

The basic form of Stoker's scheme (1961:241) follows a primary and a secondary distinction regarding the knowable. The primary distinction is between God and cosmos, ${ }^{8}$ while the secondary distinction relates to the cosmos itself, viz. the distinction between the totality of the cosmos and the diversity within the cosmos. Following the primary distinction, theology is a science of God who is trans-cosmic, while all the other sciences are cosmic sciences, in the sense that they are limited to the cosmos in their task and field. Following the secondary distinction, philosophy is the science that deals with the cosmos as a whole, while each of the special sciences is concerned with some or other unique group of phenomena within the cosmos (see Figure 1).

Of course the above description does not represent Stoker's encyclopaedic views in all their refinements and intricacies. For example, Stoker did not claim that theology directly investigates God as, say, a geologist would investigate a rock. Theology's knowledge of God is rather mediated through revelation. Stoker (1940c:307) often stated that theology is 'the science of the revealed truths of God'. Furthermore, Stoker (1935:20) included within his encyclopaedic concerns relations of coherence among the relata identified with the primary and secondary distinctions. These relations of coherence were also developed into perspectival directions ${ }^{9}$ and constituted an additional means according to which the various sciences ought to be distinguished (Stoker 1940b:104-105; see the discussion immediately preceding Figure 4 where the issue of perspectival directions emerges again).

A last example of the refinements that Stoker (1971:38-44, 1981) implemented in his encyclopaedia of the sciences is his distinction between individual, transversal and intermediary sciences. Individual sciences include theology, philosophy

\begin{tabular}{|c|c|c|c|}
\hline $\begin{array}{l}\text { Trans-cosmic } \\
\text { science }\end{array}$ & Theology & $\rightarrow$ God & \\
\hline \multirow{2}{*}{$\begin{array}{l}\text { Cosmic } \\
\text { sciences }\end{array}$} & Philosophy & $\rightarrow$ Cosmos as a whole & distinction \\
\hline & $\begin{array}{l}\text { Special } \\
\text { sciences }\end{array}$ & $\rightarrow$ Parts within the cosmos & $\begin{array}{l}\text { Secondary line of } \\
\text { distinction }\end{array}$ \\
\hline
\end{tabular}

FIGURE 1: Stoker's encyclopaedia in rudimentary form.

$8.5 t o k e r$ used the word cosmos as a synonym for 'creation.'

9.'Perspectival direction' is used here as the English equivalent of Stoker's Afrikaans neologism 'blikrigting' ('gaze' + 'direction'). Stoker was not original in employing 'direction' as an additional means of demarcation. According to Van der Walt 'direction' as an additional means of demarcation. According to Van der Walt
$(1968: 125,251,258,262,273,279)$ this is in line with a long tradition of reformed theological thought, and is also found with Thomas Aquinas. 
and each of the special sciences. Transversal sciences are scientific disciplines that deal with those questions that the individual sciences have in common. Transversal sciences therefore transect or transverse all the individual sciences. ${ }^{10}$ As the name suggests, intermediary sciences are, in a sense, positioned in between two individual sciences. Biochemistry and chemical biology, for instance, are two intermediary sciences situated between chemistry and biology.

\section{A qualified theology-based approach}

Coming back to Stoker's theology-based approach to the development of a Christian philosophy, the following four points should be noted:

First, in Stoker's encyclopaedic scheme there is a stronger association between theology and the Bible as a source of knowledge than there is between the cosmic sciences and the Bible. For instance, Stoker (1933c:27; 1940c:298) stated that the Bible is the given source of knowledge for theology and that it is primarily for theology. The reason for this may possibly lie in the trans-cosmic concerns of theology and the consequent need for a revelation. In other words, whereas philosophy and the special sciences have direct access to the cosmos (Stoker 1940a:10), theology must appeal to the Bible as an intra-cosmic revelation from and about a trans-cosmic reality.

The stronger association between theology and the Bible may lead one to infer a straightforward dualism between God, the Bible and theology on the one hand, and the cosmos, general revelation and the cosmic sciences on the other. This would, however, be a simplistic interpretation of Stoker's views.

In the first place, Stoker (1971) held that:

the distinction between theology and philosophy does not (...) coincide with that between the revelation of God in his Word on the one hand and the cosmos (...) on the other. (p. 39)

According to him all the sciences, including theology, deal with the cosmos. This is due to the postulated coherences between the three related existents, namely God, the cosmic totality and the cosmic diversity, as well as the three correlated 'perspectival directions' (Stoker 1961:240-244).

In the second place, he believed that from a Christian perspective the Bible is a legitimate source of knowledge for all scientific disciplines. ${ }^{11}$

If the two above-mentioned reasons are legitimate, should a privileged relation between theology and the Bible then not

10.According to Stoker (1971:41), every scientific discipline has a concern with, and contributes to, the delimitation of its own field of research relative to the domains of all the other disciplines. All neighbours have a say in determining boundary lines. What he calls the 'theory of science' or 'Wissenschaftslehre' is therefore an example of a transversal science. Stoker (1971:38) also uses the name inter-sciences for of a transversal science. Stoker (1971:38) also uses the name inter-sciences for transversal sciences. A critical question is whether the acceptance of transversa sciences still allows philosophy a domain of its own, especially where philosophy is
characterised as having some sort of totality perspective regarding the cosmos.

11.Stoker (1940c:298) expressed it as follows: 'The former [i.e. Christian scholarship] acknowledges the Bible as a necessary source of knowledge for all sciences, th latter [i.e. non-Christian scholarship] does not' (also compare Stoker 1940b:103). simply be abandoned? More importantly, would full access to Scriptures for all disciplines not be beneficial to the project of Christian scholarship? What would have been, in my view, the natural next step towards a more integral Christian approach was precluded when Stoker (1940a:11; 1947:78; 1967:225) drew on the commonly held view that competence in Bible exegesis belongs solely to theologians. Besides, methodological expertise is historically contingent, that is, malleable. A discipline's direct access to one of its acknowledged sources ought therefore not to be ruled out on the grounds that its practitioners currently lack the necessary methodological competencies. The task of a discipline, together with its sources of knowledge, should rather determine which methodological competencies are to be honed by the scholars working in that scientific domain.

Second, in Stoker's scheme theology is placed in an intermediary position between the Bible and the cosmic sciences. This is a consequence of Stoker's view that only theologians are competent to provide scientific expositions of the Bible. Stoker (1940c:303) explained that the Bible contains information that needs to be processed scientifically by means of exegesis and other supplementary methods before it can be used scientifically. Because exegesis is the expertise of theology, the non-theological scientist may not appeal to the Bible directly. Where non-theologians want to make use of biblical information scientifically, they must borrow it from the theologian. Although this does not preclude Biblebelieving philosophers and special scientists from being influenced by their pre-scientific knowledge of the Bible (Stoker 1940b:103; 1970:420-425), such knowledge cannot be used scientifically without the mediation of the theologian. This places theology as a mediator between philosophy and the Bible.

Third, reformed theology is regarded by Stoker as foundational to Calvinist philosophy. According to Stoker (1947:70-73, 75-76), questions regarding God and the relation between God and the cosmos ought to be addressed by theology. Theology's answers to these questions, in turn, form the religious apriori of philosophy. These religious apriori function as the ground idea on which a Calvinist philosophy is to be based. Stoker (1951:45) also called them 'regulative principles'; thereby indicating their regulating function in philosophical investigations of the cosmos. Moreover, according to Stoker (1970:225), they 'fundamentally and in mainlines co-determine the construction of Calvinist philosophy'.

Some examples of religious apriori mentioned by Stoker (1941c:54) that belong to the field of theology include the trans-cosmic origin, self-insufficiency, the creaturely status and the law-boundedness of the cosmos, as well as the idea that there is a cohering diversity within the cosmos. Even the question of who God is should be answered by the theologian (Stoker 1940b:108). However, together with Strauss (1969:35) it should be pointed out that these are not theological doctrines, but simply religiously determined faith convictions of a pre-scientific nature. 
Fourth, theology is placed in an elevated position with regards to all the other sciences. This seems to be an unavoidable consequence of the trans-cosmic nature of what it investigates. As Stoker (1940a:10) stated, theology investigates the revealed truths of God. Seeing that these truths are about something which is not a cosmic reality, the investigation of it cannot be the task of a special science (vakwetenskap). Being revealed truths of God they are not a part or a section (vak) of the cosmos. In Stoker's scheme, theology must be nobler than all the other sciences, because it deals with truths of a higher or more ultimate nature. Whether it is called the 'queen of the sciences'12 or, more tactfully, the 'first among equals'13 (cf. Stoker 1970:425, 1971:39), does not matter much. Theology retains an elevated position in comparison to the other sciences!

By framing the second and third points above as encyclopaedic issues, Stoker (1970:420-425) tried to present the intermediary and foundational role of theology as merely a matter of interdependence and cooperation between the sciences. ${ }^{14} \mathrm{He}$ explains that there are two different sets of problems that should not be confused: first, the set of problems regarding the 'vertical' relation between pre-scientific and scientific knowledge and second, the set of problems regarding the 'horizontal' relation between the sciences themselves.

So, when Malan (1968) criticised Stoker for supposedly wanting to Christianise philosophy via its required connections to theology, he (Stoker) argued that Malan only considered what he had said about the horizontal relation between theology and the other sciences. According to Stoker, Malan should also have considered what he had said about the vertical relation between pre-scientific and scientific knowledge. If Malan had, he would have seen that 'religious faith' (which is pre-scientific) is the dunamis of scholarship according to Stoker's view. Stoker (1970:425) thus emphatically denied having an approach according to which Christian philosophy is founded on theology. ${ }^{15}$

In this way Stoker portrayed the relation between theology and the other sciences as being situated on one and the same horizontal plane, viz. the plane of the sciences. In order to further soften the centrality of theology in his encyclopaedia, Stoker (1970:422, 425) also remarked that it is not only philosophy and the special sciences that depend on theology, but that all these sciences are interdependent. Furthermore, he argued that the cooperation between the sciences must be free and voluntary: 'The one may not rule over, dictate or prescribe to the others'. Nevertheless, close attention should be paid to what Stoker's views really amount to.

12.The well-known Latin phrase is regina scientiarum.

13.The well-known Latin phrase is primus inter pares.

14.Compare also Schutte's attempt (1972:315) to address this problem regarding Stoker's approach to Christian scholarship in the same vein.

15. Notwithstanding this denial, it should be noted that Stoker explicitly stated that it is by means of borrowing from theology that non-theological disciplines obtain their Christian character. In Stoker's own words (1952:126): 'The Holy Scriptures reveal (...) fundamental principles (...), principles which all the non-theological sciences should borrow from theology and should use as religious guiding sciences should borrow from theology and should use as religious guiding
principles in their respective domains, the borrowing and use of which give these sciences a definitely Christian character'.
Are all the sciences in Stoker's encyclopaedia truly on the same level? Apparently not, considering the trans-cosmic nature of what theology investigates. It is also doubtful that there can be true equality in the interdependence between the sciences, since what a Christian philosophy depends on theology for, is nothing less than its religious apriori, in other words its Christian character. Moreover, it should be asked how free this cooperation really is. Philosophy is 'free' to formulate its ground idea, but it must be based on the exegesis done by the theologian and under the guidance of the theologian (Stoker 1940a:11). Yes, Christian philosophers may criticise the results of theology and they are free to choose not to appropriate the results. Yet, the choice is limited to either presupposing the results or simply remaining without them. ${ }^{16}$ The latter option would lead to the absence of religious foundations on which a Christian philosophy could be developed.

From the preceding discussion of Stoker's scheme regarding the relationship between theology and the other sciences, there are clear indications of a theology-based approach. Things are not that simple, however. One of the underlying assumptions of the typical theology-based approach is that reality consists of two domains: one sacred and the other secular. The sacred is associated with God, religion, faith, church, special revelation and theology, and the secular with the world, the religiously neutral, reason, the state, general revelation and non-theological sciences. The typical theologybased approach can thus be seen as arising from the need to Christianise the otherwise religiously neutral non-theological sciences.

Where the presupposition of a sacred-secular dualism is still neatly operative, one would therefore expect to find the belief that non-theological scholarship is religiously neutral. But Stoker (1947:47-75) did not assume that. One would also expect the exclusion of the Bible as a legitimate source of knowledge for the non-theological sciences. Again, Stoker did not reject the Bible as a legitimate source for these disciplines. It therefore appears that he modified the theology-based approach so that it was slightly more in line with the ideal of an integral Christian philosophy.

Although Stoker did not subscribe to a straightforward theology-based approach, he also did not fully reject it. He modified it. Yet, defending such a position in which not only the Bible, but also several religious beliefs are effectively annexed by theology, manifests his commitment to an approach that requires theology to be the key factor in Christian scholarship. Considering both Stoker's modifications of, and his manifested commitment to a theology-based model, a fair characterisation of his approach would therefore be that it is an inconsistent or a qualified theology-based approach.

16.The reason for this limitation of choice is due to Stoker's position (1970:424-425) that does not allow philosophers the freedom of independent exegesis. According to him, using the results of such independent exegesis would amount to 'playing theologian'. 


\section{Criticising the encyclopaedic scheme and the approach related to it}

While explicating Stoker's approach in the preceding section, some critical remarks were made in passing. Nonetheless, his encyclopaedic scheme and the approach related to it require further critical examination. The points of criticism that will follow are not meant to be an exhaustive evaluation as much more could be said. The intention is rather to emphasise the problematic nature of Stoker's position.

\section{Accounting for non-Christian theology}

A first difficulty arises in the attempt to account for certain non-Christian theologies in terms of Stoker's scheme. According to Stoker, theology is the study of the revealed truths of God. The obvious question, then, is: What about non-Christian theologies that may accept neither the existence of God, nor the existence of any other trans-cosmic divinity? How can Stoker account for theologies that are directed by pagan or pantheistic divinity beliefs? According to pagan religious beliefs, the per se divine is a subdivision of the non-divine, while, according to pantheistic religious beliefs, the non-divine is a subdivision of the per se divine (Clouser 2005:48). In both cases there is only one continuous reality and no trans-cosmic being that can be assigned to theology.

Stoker (1971) addressed this issue by drawing on the idea of absolutisation:

In the case of non-Christian theology, theology is the science of that which is taken instead of God as the absolute, for instance, the 'absolute' as in the case of the 'god' of Aristotle or of Spinoza, and its relation to all 'things'. (p. 39)

In other words, for an atheist who takes matter to be absolute or self-sufficient (i.e. 'divine per se' according to Clouser's definition), theology would be the science that studies matter. For the scientist who regards numbers as self-existent, theology would be the science that deals with numbers. This proposal has some odd implications.

In defending Christian scholarship against the accusation that it 'theologises' philosophy and the special sciences, Stoker (1970:107; 2010:16) replied that it is rather those scientists who deify something within the cosmos that are in fact guilty of such theologising. Notwithstanding its wittiness, this reply points to a serious vulnerability in his scheme. From this point of view, whether theology studies God, matter, numbers, energy, life, rationality or any other conceivable intra-cosmic candidate, depends on the divinity beliefs of the respective scholar. Not only will the religious direction of theologies differ depending on the religious beliefs presupposed by it, but such diverging theologies will not even have the same field of research in common.

In addition, each one of the cosmic sciences can potentially be or become theology. The study of the laws of logic and the relations that exist between them, for example, can be called logic. However, if a logician presupposes the laws of logic to be self-existent, he or she is not occupied with logic, but with theology. Thus, determining whether a science is a cosmic science or theology does not depend only on what it studies, but also on the divinity beliefs held by the scientist.

Perhaps it may be argued that Stoker did not intend a theologised cosmic science to be seen as a genuine theology. 'Theologising', after all, also has the connotation of being illegitimate. Nevertheless, he expressly proposed absolutisations of intra-cosmic realities to replace God as the subject matter of theology in order to account for the possibility of non-Christian theologies. There is thus an ambiguity in his position, since on the one hand he seemed to recognise the need to account for non-Christian theology (cf. Stoker 1970:91; 1971:39), while on the other he regarded such scholarship as illegitimate, even describing it as pseudo science (cf. Stoker 1941c:54, 58).

\section{Conflating structure and direction}

This ambiguity in Stoker's position and the odd implications resulting from it attest to a second problem, viz. difficulties in consistently maintaining the distinction between the field of research as structure and the religious orientation of the scholarly labour as direction. A tendency to conflate structure and direction thus seems to be present with the basic scheme from which Stoker proceeds. One cannot help wondering whether this is not the unfortunate remnant of a long intellectual tradition in which the divine, situated at the apex of a hierarchical metaphysics, is the telos to which all of reality is directed. In the 'Christianised' version of this tradition, it is the object of human contemplation, viz. the divine, that ensures the Christian character of such intellectual reflection instead of its norm conformity.

Van der Walt (1968:62) therefore suggests correctly that it would be preferable to talk about 'Scriptural thought' instead of 'theocentric thought' as Stoker often did. He (1968:202) also warns against the mistaken beliefs that (1) the subject matter of theology makes it Christian, (2) that theology therefore necessarily is Christian and (3) that other scientific disciplines can only be Christian via doctrines borrowed from theology.

One could argue that Stoker $(1970: 45,91)$ did account for the distinction between structure and direction regarding scholarship by means of a dual distinction. The first distinction is between genuine (eg) and fake (oneg) science, and the second distinction relates to a genuine science that can be either true or false. This may be understood as allowing for the possibility of a theology that is not Christian in character (i.e. false), but still genuine theology.

Such an argument would run into a serious problem, however, seeing that the religious character of a scientific theory does not coincide with the question of whether it is true or false. Clouser (2005:240) points out that a hypothesis 
may be within the range of biblically motivated thinking, yet be mistaken. Similarly, the theories of non-Christians, though driven by false divinity beliefs, may be correct. Therefore, the pair of contraries as suggested by Stoker does not in itself furnish the distinction between structure and religious direction.

\section{Inconsistent application of the scheme}

The third difficulty concerns the placement of heaven, known as the world of the angels. Stoker set out a division of the sciences according to the primary division of the knowable into God and cosmos. The distinction between theology and the cosmic sciences follows this God-cosmos distinction. The question then arises: Where does heaven fit in? With the distinction between God and cosmos meant to be exhaustive, heaven can only be considered part of the cosmos. If Stoker then wishes to have a scientific discipline dedicated to the study of heaven (called 'ouranology'), such a discipline should be considered a cosmic science within his encyclopaedia, alongside philosophy and the special sciences.

But, instead of consistently following his chosen principle of division, Stoker (1961:241; 1971:38) decided to place ouranology within the ambit of theology. Stoker (1961:241) was well aware of this inconsistency, stating that it may be inconsistent, but in accordance with tradition (...) we assign ouranology as an additional task to theology'. Tradition here outweighed consistency. Can this be a remnant of the naturesuper-nature theme, in which the world of the angels is regarded as being supernatural? Figure 2 indicates the ambiguous position of heaven when cast in the nature-supernature mould.

Seeing that Stoker (1970:412) denied being influenced by the nature-super-nature theme, it would be worthwhile to consider this issue a bit further.

\section{Nature and super-nature}

The influence of the nature-super-nature theme on Stoker's approach to Christian scholarship becomes difficult to dismiss when the dual character of theology, as presented by Thomas Aquinas and Herman Bavinck, is compared with Stoker's own views. What exactly does this dual character of theology entail, and what implications does it have for philosophy? In what follows we will first look at the similarities in pattern between the views of Thomas Aquinas, Bavinck and Stoker, after which some implications for establishing a Christian philosophy will be considered.

\begin{tabular}{|c|c|c|c|c|}
\hline \multirow{2}{*}{ Theology } & Theology & $\rightarrow$ God & \multirow{2}{*}{$\begin{array}{l}\text { Super- } \\
\text { natural }\end{array}$} & God \\
\hline & Ouranology & $\rightarrow$ Heaven & & \multirow[b]{2}{*}{ Cosmos } \\
\hline $\begin{array}{l}\text { Cosmic } \\
\text { sciences }\end{array}$ & $\begin{array}{l}\text { Philosophy } \\
\text { Special } \\
\text { sciences }\end{array}$ & $\begin{array}{l}\rightarrow \text { Cosmos as a whole } \\
\rightarrow \text { Parts within the cosmos }\end{array}$ & Natural & \\
\hline
\end{tabular}

FIGURE 2: The ambiguous position of heaven (as simultaneously supernatural and creational).

\section{Similarity in pattern}

In Thomas Aquinas the dual character of theology follows the distinction between nature and super-nature, and it coincides with the dichotomy between faith and reason. Referring to different ways in which knowledge of the divine can be obtained, Aquinas said the following in his Summa Contra Gentiles (SCG):

The first is that in which man, by the natural light of reason, ascends to a knowledge of God through creatures. The second is that by which the divine truth - exceeding the human intellect descends on us in the manner of revelation, not, however, as something made clear to be seen, but as something spoken in words to be believed. (Aquinas 1955, 4.1.5)

In this quote the first source of divine knowledge is creation and natural reason is the means of obtaining it. There is a vertical line of direction in which we ascend to knowledge of the divine. The second source of divine knowledge is God who reveals himself to us. This divine knowledge is to be believed; in other words, it is appropriated by faith. Again, there is a vertical line of direction regarding knowledge, but this time descending from God to us.

The dual character of theology is clearly linked to the fact that, in addition to God, creation is brought within the ambit of theology. As philosophy is also thought to have creation as its domain of research, some further distinction is required to address an otherwise undesirable overlap between natural theology and philosophy. The solution is sought in the different senses in which theologians and philosophers are respectively interested in creation.

In contrast to philosophers, theologians are only interested in creation so as to 'ascend' from it to knowledge of God. Theology's ultimate aim is thus knowledge of God and not knowledge of creation as such. As stated by Thomas Aquinas (1955, SCG 2.4.5), natural theology 'considers creatures only in their relation to God'; philosophy 'considers creatures in themselves' (see Figure 3).

A similar pattern emerges with the reformed theologian Herman Bavinck, albeit with a few modifications. Compare his following words:

Dogmatics is (...) a scientific system of knowledge of God (...) of the knowledge which He has revealed in His Word to the church about Himself and about all creatures as standing in relation to Him. (Bavinck 1967:1:13)

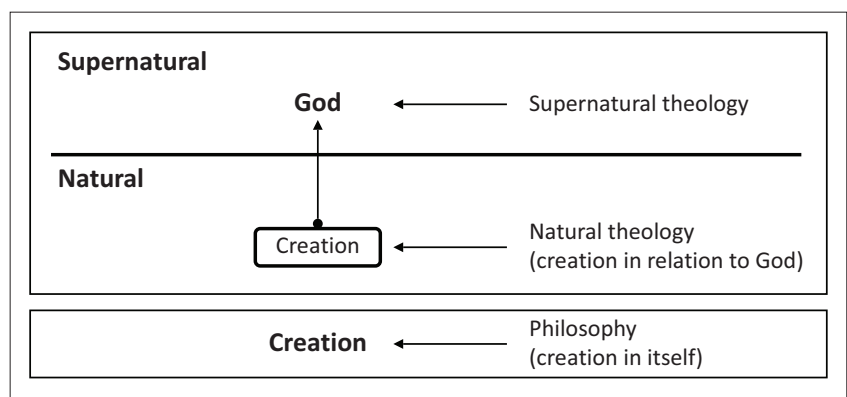

FIGURE 3: The dual character of theology in Thomas Aquinas. 
Indeed, both philosophy and theology speak about the physical world in different senses. [Philosophy] investigates the origin and nature of all things, but [theology] proceeds from God, and leads everything back to Him; it has only to do with the creatures to the extent that they are works of God and reveal some of his virtues; also where it deals with creatures, it is and always remains theology. (Bavinck 1967:2:435)

Here, too, theology has a double character, being concerned with God and creation: God as he revealed himself and creation as it stands in relation to God. Since philosophy also deals with creation, an explanation of how this discipline differs from (natural) theology is required. Hence, according to Bavinck, theology and philosophy 'speak about the physical world in different senses'. With theology it is creation in relation to God, and with philosophy it is the 'nature' of creation as such (see Figure 4).

Once again the pattern described above can also be noticed in Stoker's work. Granted, in Stoker's encyclopaedia there are not two theologies - one called natural theology and the other supernatural theology - as there are with Thomas Aquinas. Nevertheless, the single theology of Stoker still features the same dual character (cf. Van der Walt 2013:9) and the implications for philosophy are quite similar. Almost all of Stoker's descriptions of theology bear this out. ${ }^{17}$ Just compare the following two definitions:

Theology is a. the science of the revealed truths of God (e.g. his essence and attributes), and b. of the cosmic totality and cosmic diversity, insofar as they are immediately dependant on God. (Stoker 1940b:106)

Theology is the science of the truths revealed by God in His Word and in His creation about Himself and about the cosmos (as totality and as diversity) in respectu Dei, that is in the immediate relation in which God stands to His creation and to anything in it. (Stoker 1951:46)

As the ultimate aim of theology remains knowledge of God, it is primarily concerned with God and only secondarily with the cosmos. In other words, theology's interest in the cosmos is limited to the cosmos' relation to God, or as it is seen in respectu Dei. ${ }^{18}$ Philosophy, in turn, is concerned with the cosmos as such. This means that theology and philosophy respectively approach the cosmos with a distinct gaze or perspective (blik).

What is new with Stoker is that, in addition to the two perspectives on the cosmos mentioned above, he also added a special scientific perspective. Both philosophy and the special sciences are concerned with the cosmos as such, but in different senses. Philosophy is concerned with the cosmos in its totality, while the special sciences are concerned with

17.The only exception I am aware of was penned quite early in his career. There Stoker (1933a:13) restricted the field of theology to God and God's relation to creation (descending) and philosophy to creation and its relation to God (ascending). The 'descending' and 'ascending' directional relations between God and creation therefore constituted the distinction between theology and philosophy, and not a distinction within a twofold theology as it did with Thomas Aquinas and Bavinck. However, Stoker could not sustain this earlier view of his, as Aquinas and Bavinck. Howtiover, it would imply a conception of Christian philosophy that is identical to what is generally understood to be natural theology. This would have undermined his have a Christian philosophy that is distinguishable from (natural) theology.

18.It appears that, for Stoker (1941b:146), viewing creation as a revelation of God (revelatio Dei), is the same as viewing creation in its relation to God (in respectu Dei).

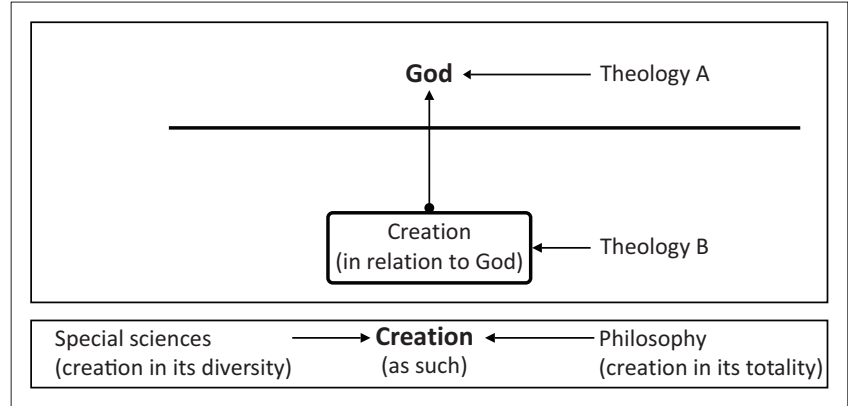

FIGURE 4: The dual character of theology in Herman Bavinck and Stoker.

the cosmos in its diversity. The strategy used to avoid an 'overlap' between (natural) theology and philosophy therefore is replicated in order to prevent an 'overlap' between philosophy and the special sciences.

\section{Integral Christian philosophy at stake?}

Stoker's views as discussed above have detrimental implications for the ideal of an integral Christian philosophy. In order to avoid encroaching on the domain of theology, philosophy is supposed to investigate creation in itself. ${ }^{19}$ In other words, it investigates creation apart from its relation to God. One should remember that, according to Stoker's definition of theology, approaching creation in its relation to God would amount to (natural) theology.

From this a philosophical conception of the cosmos logically follows according to which it is 'perspectively' presupposed to be subsisting in itself, for in one's philosophical investigation the cosmos is either seen in its dependence on God, or it is not. ${ }^{20}$ One way in which the unbiblical conception of a self-existing cosmos can still be circumvented is if the relations of creation to God, such as its dependence on God, are imported as theological presuppositions. ${ }^{21}$

This is exactly what Stoker, perhaps unconsciously, did. ${ }^{22}$ According to him (Stoker 1941b:146-147), a Christian philosophy should, in its investigation of the cosmos, presuppose the 'theological truths' such as that the cosmos was created, that it is self-insufficient and that it is subject to the law. These are the same 'religious apriori' as mentioned earlier. Note that, in the quoted definitions of philosophy below, these 'theological truths' are incorporated as a list of qualifiers describing the cosmos or, even more tellingly, placed in brackets:

19.Investigating creation 'as such' is equivalent to investigating creation 'in itself' (cf. Stoker 1941b:146). Stoker (1970:426) also used the expressions 'own nature'
('eie-aard'), 'own being' ('eie-syn') and 'own value' ('eiewaarde') more or less synonymously.

20.Stated differently, if the former option is chosen, one is no longer approaching the cosmos from a philosophical perspective. If the latter is chosen, the cosmos is seen as if it is independent of God, that is, as if it is subsisting in itself.

21.The inherent potential in theology-based approaches for theology to usurp almost everything is often less restrained than it is with Stoker. Compare for example Coletto's discussion (2009b:99-102; 2009c:29-31) of P. Bolognesi, L. De Chirico and J. Frame, as well as Strauss' critique $(2015: 202,207)$ of J. Milbank.

22.See also Stoker's response to similar criticism raised by Dooyeweerd (1957:3:68) and Malan (1968:133). To reaffirm his belief in the self-insufficiency of the cosmos, Stoker (1970:427) was compelled to place the cosmos within the context of its relation to God which, according to his own definition, implies a theological and not a philosophical perspective on the cosmos. He seems to be unaware of this inconsistency. 
Philosophy is a. the science of the (God created) self-insufficient, law-bounded cosmic totality, and $b$. of the place that the respective, cosmic-irreducible and law-bounded groups of phenomena take within this cosmic totality. (Stoker 1940b:106)

Philosophy is the science of the (God created and governed, selfinsufficient, law-bounded) cosmos as totality and of the place that any particular cosmic given takes within this totality. (Stoker 1951:46)

Stoker's way of delineating philosophy and theology therefore does not proceed from a philosophical perspective of the cosmos that is from the outset Christian. Instead, some manoeuvring is required in an attempt to neutralise the unbiblical implications, making the possibility of having a Christian philosophy once again dependent on theology.

\section{Establishing pseudo congruency}

In addition to it being a pattern of thought with negative implications, nature and super-nature is, as Vollenhoven (2011:204) explained, also a method of synthesis. ${ }^{23}$ With Stoker's theology-based approach the intention is to synthesise or reconcile the scholastic tradition in reformed theology with reformational philosophy. After all, a theologybased approach in a sense requires Christian philosophers to accept what is offered to them by reformed theology. Stoker's synthesis, with its philosophical substrate and theological superstructure, entails some complexities and a variety of adjustments.

On at least one occasion, what Stoker presented as a balanced synthesis was actually the reformational position on the particular issue being fully eclipsed by the reformed scholastic one. This is seen in one of his articles (1940a) dealing with the relation between the fields of theology and philosophy. For the broader context, Stoker mentioned the crisis in which Calvinist thinkers in the Netherlands found themselves due to the conflict between Hepp and his followers on the one hand, and the position of Vollenhoven and Dooyeweerd on the other. The views and perceived dangers of the competing sides in the conflict were juggled by Stoker with the purpose of finding the preferred middle ground. Despite the appearance of dealing with the disagreements even-handedly, reformational philosophy actually bore the brunt of the required compromise. In practice, the whole dispute was decided in favour of the orthodox view held by reformed theologians of that time, without really addressing the criticisms brought against it by reformational philosophers. ${ }^{24}$

23.The pattern is a method of synthesis in that it organises the two bodies of knowledge to be synthesised into two distinct spheres, viz. nature and supernature.

24.Stoker (1940a:10) thought that Dooyeweerd's designation of theology as a special science had in view the difference between God's infinitely higher 'science' of himself and our humanly limited science of God. In other words, Stoker misunderstood Dooyeweerd as merely reaffirming the scholastic distinction between theologia archetypa and theologia ectypa (see the critical discussion of this distinction by Strauss 2010:139). As a consequence, Stoker's argument that this distinction by Strauss 2010:139). As a consequence, Stoker's argument that theology is not a special science, because the truths about God are not a part of the cosmos, in effect begs the question. His argument already takes for granted that theology is a science of God, which is exactly what reformational philosophers were disputing. Many years later, Stoker (1971:39, 456 footnote 26) repeated similar circular argument against theology being 'degraded' to a special science.
In another instance Stoker shared a theory with other reformational philosophers, but had to restrict its implementation so as not to conflict openly with the scholastic notions he inherited from theologians like Bavinck and Hepp. This happened with Stoker (1961:164-167) adopting the reformational theory of aspects, but avoiding its application to questions pertaining to the encyclopaedia of the sciences. That would have brought him too close to the idea that theology is a special science delimited in its field of study by a fiduciary perspective on reality. Instead, he continued to delimit the particular sciences in terms of objects or things. In his own formulations, for example, Stoker speaks of 'phenomena' (1940c:307), a 'section' or 'part' of the cosmos (1947:71), 'givens' (1961:242) and 'things' (1971:39). ${ }^{25}$

In addition the philosophical influences on Stoker's work from outside Calvinist circles should also be kept in mind not only on the philosophical 'substrate' of the synthesis, but also on its theological 'superstructure'. Regarding the former, certain facets of Stoker's epistemology, for instance, owe more to Max Scheler's phenomenology than they do to reformational philosophy. What Stoker used to philosophically elaborate the fourth type of revelation distinguished by Bavinck and Hepp, viz. the revelation of the created universe to the human knower (cf. Stoker 1971:30), was Scheler's idea of the revealing character of phenomena (cf. Stoker 1967:239; Van der Walt 2013:9).

Regarding the theological 'superstructure', it should be considered that reformed theology had developed since the 16th century Reformation in the absence of a Calvinist philosophy. Seeing that a pure theology without any philosophical presuppositions is impossible (Strauss 2002), it stands to reason that some non-Christian philosophical concepts found their way into reformed theology. To the extent that these were commonly accepted, they became part of reformed orthodoxy. It is from these that Vollenhoven and Dooyeweerd wanted to untangle Calvinist thought.

All the detail of the resulting synthesis cannot be analysed fully here. However, the above may suffice as an illustration of its complexities. Two lessons deserve emphasis: First, even where obvious incompatibilities are addressed and logical contradictions are avoided by means of slight alterations of ideas and theories, the resulting synthesis may still not be fully congruent. For even if, by reshaping it, a puzzle piece can be fitted snugly into a slot, the picture thus formed will not necessarily be an accurate semblance of the one on the box. Second, heed should be taken of the real threat that, with a departure from the anti-synthetic attitude of reformational philosophy, some of its most promising innovations could be made ineffectual. This is what I suspect was, to some extent, the fate of the theory of modal aspects in Stoker's philosophy.

25.The problem is that human behaviour, for instance, can be a field of study for psychologists, historians, ethicists, sociologists, economists, et cetera, which means that the human being as an entity cannot function as a criterion for demarcating these disciplines from each other (see also Clouser 2005:161-163). demarcating these disciplines from each other (see also Clouser 2005:161-163).
Stoker (1940b:103) realised that 'theology, philosophy and the various special Stoker (1940b:103) realised that "theology, philosophy and the various special
sciences investigate the same phenomena, for example the human being, his soul, ife, matter ["stof"], time, space (...) and hence proposed the idea of perspectiva irections as a solution to this problem. It is not clear, however, how this second principle of division is to solve the problem of the overlap between the fields of study of the special sciences themselves, since in Stoker's view, they all share the same perspectival direction. 


\section{Conclusion}

In this article it was argued that Stoker did not assume the same critical posture as Vollenhoven and Dooyeweerd towards their immediate Calvinist predecessors. As attested to by Stoker's life-long deliberation on encyclopaedic issues, he availed himself of a slightly modified theology-based approach. As his encyclopaedia and approach displayed the nature-super-nature scheme, they could fulfil a synthesis function suited to Stoker's dual commitment to reformed scholasticism and reformational philosophy.

The desire to bring the theological and philosophical insights of Calvinist scholars together is understandable. However, a fundamental choice presented itself to Stoker - either to maintain scholasticism's persistent need for accommodation as a strategy, or to strive for continual reformation. As the title of Dooyeweerd's trilogy 'Reformation and Scholasticism in Philosophy' reminds us, these remain the two basic options. By opting for an uneasy union, Stoker seemed unable to come to terms with reformational criticism against scholasticism.

That Stoker still made valuable contributions is by no means excluded by this critical account of his approach. Rather, the suggestion is that reformational philosophers may find this article useful in future attempts at interpreting his philosophy and evaluating his proposals.

\section{Acknowledgements Competing interests}

The author declares that he has no financial or personal relationships which may have inappropriately influenced him in writing this article.

\section{References}

Aquinas, T., 1955, Summa contra Gentiles, 4 Books, transl. A.C. Pegis, J.F. Anderson, V.J. Bourke \& C.J. O'Neil, Hanover House, New York.

Bavinck, H., 1967, Gereformeerde dogmatiek, Vier delen, J.H. Kok, Kampen.

Clouser, R.A., 2005, The myth of religious neutrality: An essay on the hidden role of religious belief in theories, rev. edn., University of Notre Dame Press, Notre Dame, IN.

Coletto, R., 2009a, 'Strategies towards a reformation of the theology-based approach to Christian scholarship', In die Skriflig 43(2), 291-313. http://dx.doi.org/10.4102/ ids.v43i2.225

Coletto, R., 2009b, 'Theology and philosophy: The controversies concerning their nature and role in the reformational tradition', Journal for Christian Scholarship 45(3), 97-115

Coletto, R., 2009c, 'Christian scholarship within reformed circles', Acta Academica 41(3), 16-41.

Dooyeweerd, H., 1939, 'Kuyper's wetenschapsleer', Philosophia Reformata 4(1) 193-232. http://dx.doi.org/10.1163/22116117-90000686

Dooyeweerd, H., 1957, A new critique of theoretical thought, vol. 3, Presbyterian and Reformed Publishing Company, Philadelphia, PA.

Dooyeweerd, H., 1958, 'De verhouding tussen wijsbegeerte en theologie en de strijd der faculteiten, I', Philosophia Reformata 23(1\&2), 1-21. http://dx.doi. org/10.1163/22116117-90000962

Hart, H., 1971, 'Malan's critical study', in Truth and reality: Philosophical perspectives on reality dedicated to professor Dr. H.G. Stoker, pp. 109-121, De Jong's Bookshop, Braamfontein

Heyns, J.A., 1994, 'Die betekenis van H.G. Stoker se filosofie vir die teologie', Koers Bulletin for Christian Scholarship 59(3\&4), 455-471.

Malan, D.J., 1968, "n Kritiese studie van die wysbegeerte van H.G. Stoker vanuit die standpunt van H. Dooyeweerd', PhD thesis, Faculty of Law, The Free University of Amsterdam.
Norval, E.J.G., 1950, 'Die onderskeid en die verband tussen die teologiese etiek, wysgerige etiek en vakwetenskaplike etiek: met besondere toespitsing op die onderskeid en verband tussen Gereformeerd-teologiese etiek, Calvinistieswysgerige etiek en Christelike-vakwetenskaplike etiek', MA dissertation, PU for CHE, University of South Africa, Potchefstroom.

Raath, A.W.G., 1994, 'Soli Deo gloria: die lewe en werk van prof. dr. H.G. Stoker (4 April 1899-16 Mei 1993)', Koers - Bulletin for Christian Scholarship 59(3\&4), 343-361.

Schutte, B.J., 1972, 'Die noodwendigheid van 'n Christelike wetenskap in die wetenskapsleer van H.G. Stoker', PhD verhandeling, Fakulteit Lettere en Wysbegeerte, Randse Afrikaanse Universiteit, Johannesburg.

Stellingwerff, J., 2006, Geschiedenis van de reformatorische wijsbegeerte: een Christelijke perspectief, Stichting voor reformatorische wijsbegeerte, Amersfoort.

Stoker, H.G., 1927, 'Oor enkele grondbeginsels van 'n teïstische filosofie, I-VIII', Woord en Geest: Gereformeerde Weekblad 3(3-11), 3-83.

Stoker, H.G., 1933a, Die wysbegeerte van die skeppingsidee of grondbeginsels van 'n Kalvinistiese wysbegeerte, De Bussy, Pretoria.

Stoker, H.G., 1933b, Die nuwere wysbegeerte aan die Vrije Universiteit (Amsterdam), De Bussy, Pretoria.

Stoker, H.G., 1933c, Die slakkehuisteorieë van die bewussyn of iets oor die wese van die bewussyn, De Bussy, Pretoria.

Stoker, H.G., 1935, 'The possibility of a Calvinistic philosophy', The Evangelical Quarterly 7, 17-23.

Stoker, H.G., 1937a, 'God (Theos) en wêreld (kosmos)', Koers - tweemaandelikse tydskrif 4(4), 4-13.

Stoker, H.G., 1937b, 'Grepe uit die wysbegeerte van die wetsidee: "ken uself"', Koers - tweemaandelikse tydskrif 5(1), 11-17.

Stoker, H.G., 1937c, 'Grepe uit die wysbegeerte van die wetsidee: sy naam', Koers tweemaandelikse tydskrif 5(2), 17-24.

Stoker, H.G., 1937d, 'Grepe uit die wysbegeerte van die wetsidee: sy verhouding tot vakwetenskappe', Koers - tweemaandelikse tydskrif 5(3), 22-27.

Stoker, H.G., 1938a, 'Grepe uit die wysbegeerte van die wetsidee: die wetskringe', Koers - tweemaandelikse tydskrif 5(4), 33-39.

Stoker, H.G., 1938b, 'Grepe uit die wysbegeerte van die wetsidee: nog eens die wetskringleer', Koers - tweemaandelikse tydskrif 6(1), 8-14.

Stoker, H.G., 1938c, 'Grepe uit die wysbegeerte van die wetsidee: die individualiteitstrukture', Koers - tweemaandelikse tydskrif 6(2), 24-30.

Stoker, H.G., 1939, 'Grepe uit die wysbegeerte van die wetsidee: die subjek-objekrelasie', Koers - tweemaandelikse tydskrif 6(5), 16-23.

Stoker, H.G., 1940a, 'Grepe uit 'n Calvinistiese wysbegeerte: die verhouding tussen teologie en wysbegeerte', Koers - tweemaandelikse tydskrif 7(6), 1-11.

Stoker, H.G., 1940b, 'Grepe uit 'n Calvinistiese wysbegeerte: terreinafbakening tussen teologie, wysbegeerte en vakwetenskap', Koers - tweemaandelikse tydskrif 8(3), $101-111$.

Stoker, H.G., 1940c, 'Beginsels van 'n Christelike wetenskapsleer', in H.G. Stoker \& J.D. Vorster (reds.), Koers in die krisis, II: Artikels versamel deur die Federasie van die Calvinistiese Studenteverenigings in Suid-Afrika, pp. 293-331, Pro Ecclesia, Stellenbosch.

Stoker, H.G., 1941a, 'Grepe uit die wysbegeerte van die wetsidee: selfbesinning en wysbegeerte', Koers - tweemaandelikse tydskrif 8(6), 219-228.

Stoker, H.G., 1941b, 'Grepe uit 'n Calvinistiese wysbegeerte: phanerosis en wysbegeerte', Koers - tweemaandelikse tydskrif 8(4), 140-149.

Stoker, H.G., 1941c, 'Grepe uit 'n Calvinistiese wysbegeerte: palingenesie en wysbegeerte', Koers - tweemaandelikse tydskrif 9(2), 49-58.

Stoker, H.G., 1947, 'Calvinistiese wysbegeerte', Standpunte - onafhanklike Kwartaalblad vir Literatuur en Kuns 2(3), 68-78.

Stoker, H.G., 1951, 'Teologiese, wysgerige en vakwetenskaplike etiek', in Wetenschappelijke Bijdragen door leerlingen van dr. D.H.Th. Vollenhoven aangeboden ter gelegenheid van zijn 25-jarige hoogleraarschap aan de Vrije Universiteit, pp. 44-51, T Wever, Franeker.

Stoker, H.G., 1952, 'Scriptural truths and scientific thought', The Calvin Forum 17(7), $124-130$

Stoker, H.G., 1961, Beginsels en metodes in die wetenskap, Pro Rege, Potchefstroom.

Stoker, H.G., 1962, 'Die beginsel: eenheid en differensiasie', Koers - maandblad vir Calvinistiese denke 30(1\&2), 20-45.

Stoker, H.G., 1967, Oorsprong en rigting, band 1, Tafelberg Publishers, Cape Town.

Stoker, H.G., 1970, Oorsprong en rigting, band 2, Tafelberg Publishers, Cape Town.

Stoker, H.G., 1971, 'Reconnoitering the theory of knowledge of Prof. Dr. Cornelius van Til', in E.R. Geehan, (ed.), Jerusalem and Athens: Critical discussions on the theology and apologetics of Cornelius van Til, pp. 25-71, Presbyterian and Reformed Publishing Company, Philadelphia, PA.

Stoker, H.G., 1981, 'Oopheid in die wetenskap', inaugural address as honorary professor in the Department of Philosophy at the PU for CHE, in Uit, deur en to God is alle dinge: werke van Prof. Dr. H.G. Stoker, CD, Association for Christian Higher Education, Bloemfontein.

Stoker, H.G., 2007, 'Formele struktuur van tyd', in Uit, deur en tot God is alle dinge: werke van Prof. Dr. H.G. Stoker, CD, Association for Christian Higher Education, Bloemfontein.

Stoker, H.G., 2010, Philosophy of the creation idea, transl. by J.L. van der Walt, School of Philosophy, Potchefstroom Campus, North-West University, Potchefstroom. 
Strauss, D.F.M., 1969, 'Wysbegeerte en vakwetenskap', MA dissertation, Philosophy Department, University of the Free State, Sacum, Bloemfontein.

Strauss, D.F.M., 2002, 'Is it possible to do theology without philosophical presuppositions?', Acta Theologica 22(1), 146-164. http://dx.doi.org/10.4314/ actat.v22i1.5400

Strauss, D.F.M., 2010, “"God in himself" and "God as revealed to us": the impact of the substance concept', Acta Theologica 30(1), 123-144.

Strauss, D.F.M., 2015, 'Theology and philosophy within radical orthodoxy (Milbank) and reformational philosophy (Dooyeweerd)', Acta Theologica 35(1), 201-221. http://dx.doi.org/10.4314/actat.v35i1.12

Tol, A., 2011, 'Reformational philosophy in the making', Philosophia Reformata 76(2), 187-215. http://dx.doi.org/10.1163/22116117-90000516

Van der Stelt, J.C., 2012, Herman Bavinck (1854-1921), chapter 4, unpublished manuscript.
Van der Walt, B.J., 1968, Die wysgerige konsepsie van Thomas van Aquino in sy 'Summa contra gentiles' met spesiale verwysing na sy siening van teologie, MA dissertation (unabridged), Faculty of Arts, PU for CHE, Potchefstroom.

Van der Walt, B.J, 2007, 'Ad fontes: eerste boustene vir 'n geskiedenis van die reformatoriese filosofie - ook in Suid-Afrika', Journal for Christian Scholarship 43(3\&4), 217-234.

Van der Walt, B.J., 2013, 'H.G. Stoker (1999-1993) as Christelike filosoof: 'n historiese legende en ikoon, of nog steeds'n kontemporêre mentor?', In Die Skriflig/In Luce Verbi 47(1), Art. \#86, 15 pages. http://dx.doi.org/10.4102/ids.v47i1.86

Van der Walt, S.P., 1953, 'Die wysbegeerte van Dr. Herman Bavinck', PhD verhandeling, Universiteit van Suid-Afrika, Pro Rege, Potchefstroom.

Vollenhoven, D.H.Th., 2011, Gastcolleges wijsbegeerte: erfenis voor het heden, in K.A. Bril \& R.A. Nijhoff (eds.), De Zaak Haes, Amstelveen. 